\title{
Communication
}

\section{Secondary Metabolites from the Soft Coral Sinularia arborea}

\section{Kuan-Hua Chen ${ }^{1,2}$, Chang-Feng Dai ${ }^{3}$, Mei-Chin Lu ${ }^{1,2}$, Jan-Jung Li $^{2}$, Jih-Jung Chen ${ }^{4}$, Yu-Chia Chang ${ }^{2,5}$, Yin-Di Su ${ }^{2,6}$, Wei-Hsien Wang ${ }^{2,6}$ and Ping-Jyun Sung ${ }^{1,2,7,8, *}$}

1 Graduate Institute of Marine Biotechnology, National Dong Hwa University, Pingtung 944, Taiwan; E-Mails: asdfgh0213@gmail.com (K.-H.C.); jinx6609@nmmba.gov.tw (M.-C.L.)

2 National Museum of Marine Biology and Aquarium, Pingtung 944, Taiwan;

E-Mails: jj@nmmba.gov.tw (J.-J.L.); jay0404@gmail.com (Y.-C.C.); gobetter04@yahoo.com.tw (Y.-D.S.);whw@nmmba.gov.tw (W.-H.W.)

3 Institute of Oceanography, National Taiwan University, Taipei 106, Taiwan; E-Mail: corallab@ntu.edu.tw

4 Department of Pharmacy and Graduate Institute of Pharmaceutical Technology, Tajen University, Pingtung 907, Taiwan; E-Mail: jjchen@mail.tajen.edu.tw

5 Doctoral Degree Program in Marine Biotechnology, National Sun Yat-sen University and Academia Sinica, Kaohsiung 804, Taiwan

6 Department of Marine Biotechnology and Resources and Division of Marine Biotechnology, Asia-Pacific Ocean Research Center, National Sun Yat-sen University, Kaohsiung 804, Taiwan

7 Natural Medicinal Products Research Center, China Medical University Hospital, Taichung 404, Taiwan

8 Graduate Institute of Natural Products, Kaohsiung Medical University, Kaohsiung 807, Taiwan

* Author to whom correspondence should be addressed; E-Mail: pjsung@nmmba.gov.tw; Tel.: +886-8-882-5037; Fax: +886-8-882-5087.

Received: 10 July 2013; in revised form: 16 August 2013 / Accepted: 26 August 2013 / Published: 3 September 2013

\begin{abstract}
Two new 13-hydroxycembrane diterpenoids, arbolides A (1) and B (2), along with a known trihydroxysteroid, crassarosterol A (3), were isolated from the soft coral Sinularia arborea. The structures of new cembranes $\mathbf{1}$ and $\mathbf{2}$ were elucidated by spectroscopic methods. Steroid 3 was found to exhibit cytotoxicity toward K562 and MOLT-4 leukemia.
\end{abstract}

Keywords: cembrane; Sinularia arborea; arbolide; crassarosterol; cytotoxicity 


\section{Introduction}

Previous studies on the chemical constituents of soft corals belonging to the genus Sinularia have led to the isolation of a number of interesting secondary metabolites and some of these were found to possess extensive bioactivities [1-3]. Continuation investigation on the chemical constituents of the marine invertebrates collected off the waters of Taiwan, two new cembrane-type diterpenoids, arbolides A (1) and B (2), and a known steroid, crassarosterol A (3) [4], were isolated from the soft coral Sinularia arborea (family Alcyonacea) (Figure 1). In this paper, we describe the isolation, structure determination and cytotoxicity of compounds $\mathbf{1}-\mathbf{3}$.

Figure 1. The soft coral Sinularia arborea and the structures of arbolides A (1), B (2) and crassarosterol A (3).

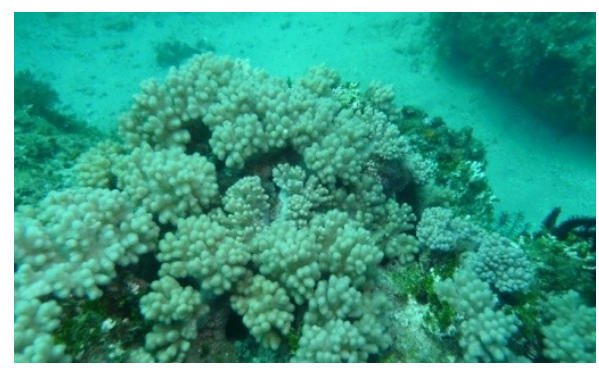

Sinularia arborea

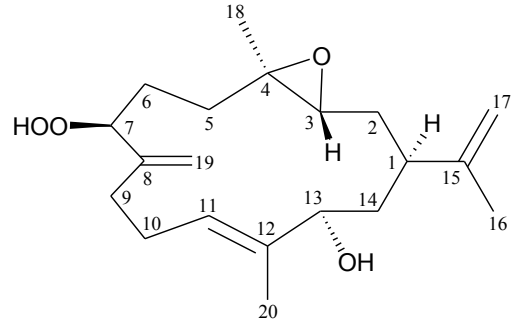

1

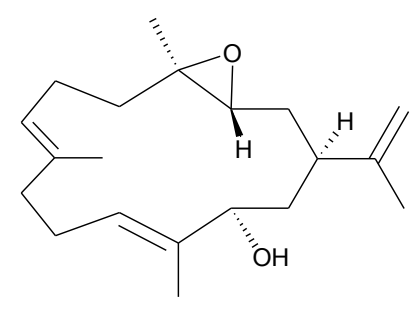

2

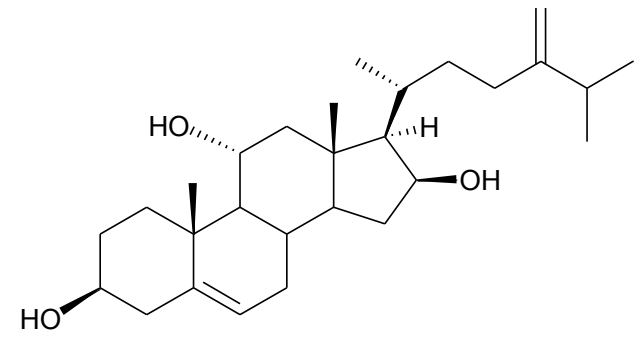

3

\section{Results and Discussion}

Arbolide A (1) was isolated as a colorless oil that gave a pseudomolecular ion $[\mathrm{M}+\mathrm{Na}]^{+}$at $\mathrm{m} / z$ 359.2195 in the HRESIMS, indicating the molecular formula $\mathrm{C}_{20} \mathrm{H}_{32} \mathrm{O}_{4}$ (calcd for $\mathrm{C}_{20} \mathrm{H}_{32} \mathrm{O}_{4} \mathrm{Na}$, 359.2198 ) ( $5^{\circ}$ of unsaturation). The IR spectrum of 1 showed a broad band at $3345 \mathrm{~cm}^{-1}$, consistent with the presence of hydroxy group. The ${ }^{13} \mathrm{C}$ NMR and DEPT spectra of $\mathbf{1}$ showed that this compound had 20 carbons (Table 1), including three methyls, six $\mathrm{sp}^{3}$ methylenes, two $\mathrm{sp}^{2}$ methylenes, four $\mathrm{sp}^{3}$ methines, an $\mathrm{sp}^{2}$ methine, an $\mathrm{sp}^{3}$ quaternary carbon and three $\mathrm{sp}^{2}$ quaternary carbons. The presence of a trisubstituted epoxide containing a methyl substituent was established from the NMR signals at $\delta_{\mathrm{C}} 61.4$ $(\mathrm{CH}), 61.1(\mathrm{C})$ and $\delta_{\mathrm{H}} 2.72(1 \mathrm{H}, \mathrm{dd}, J=6.0,6.0 \mathrm{~Hz})$ and further confirmed by the proton signal of a methyl singlet at $\delta_{\mathrm{H}} 1.27(3 \mathrm{H}, \mathrm{s})$ (Table 1). A trisubstituted and two 1,1-disubstituted carbon-carbon double bonds were identified from the NMR signals at $\delta_{\mathrm{C}} 138.4(\mathrm{C}), 125.3(\mathrm{CH})$ and $\delta_{\mathrm{H}} 5.48(1 \mathrm{H}$, br s); $\delta_{\mathrm{C}} 147.3(\mathrm{C}), 113.2\left(\mathrm{CH}_{2}\right)$ and $\delta_{\mathrm{H}} 5.19(1 \mathrm{H}, \mathrm{s}), 5.15(1 \mathrm{H}, \mathrm{s}) ; \delta_{\mathrm{C}} 148.1(\mathrm{C}), 111.2\left(\mathrm{CH}_{2}\right)$ and $\delta_{\mathrm{H}} 4.75(2 \mathrm{H}$, br s), respectively. A hydroperoxy-bearing methine $\left(\delta_{\mathrm{H}} 4.38,1 \mathrm{H}, \mathrm{dd}, J=7.2,4.8 \mathrm{~Hz}, \delta_{\mathrm{C}} 88.4, \mathrm{CH}\right)$ [5-7] and a hydroxy-bearing methine $\left(\delta_{\mathrm{H}} 3.92,1 \mathrm{H}, \mathrm{dd}, J=6.0,6.0 \mathrm{~Hz}, \delta_{\mathrm{C}} 76.4, \mathrm{CH}\right)$ were identified from the 
characteristic NMR signal analysis. These data, combined with the five degrees of unsaturation implied by the molecular formula, suggested a bicyclic structure for $\mathbf{1}$.

Table 1. ${ }^{1} \mathrm{H}\left(400 \mathrm{MHz}, \mathrm{CDCl}_{3}\right)$ and ${ }^{13} \mathrm{C}\left(100 \mathrm{MHz}, \mathrm{CDCl}_{3}\right) \mathrm{NMR}$ data, ${ }^{1} \mathrm{H}-{ }^{1} \mathrm{H}$ COSY and HMBC correlations for cembrane $\mathbf{1}$.

\begin{tabular}{|c|c|c|c|c|}
\hline Position & $\delta_{\mathrm{H}}(J$ in $\mathrm{Hz})$ & $\delta_{\mathrm{C}}$, Multiple & ${ }^{1} \mathrm{H}_{-1}{ }^{1} \mathrm{H} \mathrm{COSY}$ & HMBC \\
\hline 1 & $2.02 \mathrm{~m}$ & $43.1, \mathrm{CH}$ & $\mathrm{H}_{2}-2, \mathrm{H}_{2}-14$ & $\mathrm{C}-2,-3,-13,-15,-17$ \\
\hline 2 & $1.89 \mathrm{~m} ; 1.23 \mathrm{~m}$ & $32.9, \mathrm{CH}_{2}$ & H-1, H-3 & $C-1,-3,-4,-14,-15$ \\
\hline 3 & $2.72 \mathrm{dd}(6.0,6.0)$ & $61.4, \mathrm{CH}$ & $\mathrm{H}_{2}-2$ & $\mathrm{C}-2$ \\
\hline 4 & & 61.1, C & & \\
\hline 5 & $1.96 \mathrm{~m} ; 1.30 \mathrm{~m}$ & $33.7, \mathrm{CH}_{2}$ & $\mathrm{H}_{2}-6$ & $C-3,-4,-6,-7,-18$ \\
\hline 6 & $1.66 \mathrm{~m} ; 1.52 \mathrm{~m}$ & 28.6, $\mathrm{CH}_{2}$ & $\mathrm{H}_{2}-5, \mathrm{H}-7$ & $C-4,-5,-7,-8$ \\
\hline 7 & $4.38 \mathrm{dd}(7.2,4.8)$ & $88.4, \mathrm{CH}$ & $\mathrm{H}_{2}-6$ & $C-5,-6,-19$ \\
\hline 8 & & 147.3, C & & \\
\hline 9 & $2.24 \mathrm{~m}$ & $31.3, \mathrm{CH}_{2}$ & $\mathrm{H}_{2}-10, \mathrm{H}_{2}-19$ & C- $8,-10,-11$ \\
\hline 10 & $2.41 \mathrm{~m} ; 2.27 \mathrm{~m}$ & $25.9, \mathrm{CH}_{2}$ & $\mathrm{H}_{2}-9, \mathrm{H}-11$ & C-9 \\
\hline 11 & 5.48 br s & $125.3, \mathrm{CH}$ & $\mathrm{H}_{2}-10, \mathrm{H}_{3}-20$ & n.o. ${ }^{a}$ \\
\hline 12 & & $138.4, \mathrm{C}$ & & \\
\hline 13 & $3.92 \mathrm{dd}(6.0,6.0)$ & $76.4, \mathrm{CH}$ & $\mathrm{H}_{2}-14$ & $C-1,-12,-14,-20$ \\
\hline 14 & $1.80 \mathrm{dd}(6.8,6.0)$ & $38.2, \mathrm{CH}_{2}$ & H-1, H-13 & $C-1,-2,-12,-13,-15$ \\
\hline 15 & & 148.1, C & & \\
\hline 16 & $1.71 \mathrm{br} \mathrm{s}$ & $18.8, \mathrm{CH}_{3}$ & $\mathrm{H}_{2}-17$ & $C-1,-15,-17$ \\
\hline 17 & $4.75 \mathrm{br} \mathrm{s}$ & 111.2, $\mathrm{CH}_{2}$ & $\mathrm{H}_{3}-16$ & $C-1,-15,-16$ \\
\hline 18 & $1.27 \mathrm{~s}$ & 17.0, $\mathrm{CH}_{3}$ & & $C-3,-4,-5$ \\
\hline 19 & $5.19 \mathrm{~s} ; 5.15 \mathrm{~s}$ & $113.2, \mathrm{CH}_{2}$ & $\mathrm{H}_{2}-9$ & $C-7,-8,-9$ \\
\hline 20 & $1.69 \mathrm{~s}$ & 13.6, $\mathrm{CH}_{3}$ & $\mathrm{H}-11$ & $\mathrm{C}-11,-12,-13$ \\
\hline 7-OOH & 7.89 br s & & & n.o. \\
\hline
\end{tabular}

From the ${ }^{1} \mathrm{H}-{ }^{1} \mathrm{H}$ COSY spectrum of $\mathbf{1}$ (Table 1 and Figure 2), the separate spin systems of $\mathrm{H}-13 / \mathrm{H}_{2}-14 / \mathrm{H}-1 / \mathrm{H}_{2}-2 / \mathrm{H}-3, \mathrm{H}_{2}-5 / \mathrm{H}_{2}-6 / \mathrm{H}-7$ and $\mathrm{H}_{2}-9 / \mathrm{H}_{2}-10 / \mathrm{H}-11$ were differentiated. These data, together with the key HMBC correlations between protons and quaternary carbons (Table 1 and Figure 2), such as $\mathrm{H}_{2}-2, \mathrm{H}_{2}-5, \mathrm{H}_{2}-6, \mathrm{H}_{3}-18 / \mathrm{C}-4 ; \mathrm{H}_{2}-6, \mathrm{H}_{2}-9 / \mathrm{C}-8 ; \mathrm{H}-13, \mathrm{H}_{2}-14 / \mathrm{C}-12 ;$ and $\mathrm{H}-1, \mathrm{H}_{2}-2, \mathrm{H}_{2}-14$, $\mathrm{H}_{2}-17 / \mathrm{C}-15$, established the main carbon skeleton of 1 . The vinyl methyls at $\mathrm{C}-12$ and $\mathrm{C}-15$ were confirmed by the HMBC correlations between $\mathrm{H}_{3}-20 / \mathrm{C}-11,-12,-13$ and $\mathrm{H}_{3}-16 / \mathrm{C}-1,-15$, -17; and further supported by the allylic couplings between $\mathrm{H}-11 / \mathrm{H}_{3}-20$ and $\mathrm{H}_{2}-17 / \mathrm{H}_{3}-16$ in the ${ }^{1} \mathrm{H}-{ }^{1} \mathrm{H}$ COSY spectrum of 1. The exocyclic carbon-carbon double bonds at C-8 and C-15 were established by the HMBC correlations between $\mathrm{H}_{2}-19 / \mathrm{C}-7,-8,-9$ and $\mathrm{H}_{2}-17 / \mathrm{C}-1,-15,-16$; and further confirmed by the allylic couplings between $\mathrm{H}_{2}-9 / \mathrm{H}_{2}-19$ and $\mathrm{H}_{2}-17 / \mathrm{H}_{3}-16$ in the ${ }^{1} \mathrm{H}-{ }^{1} \mathrm{H}$ COSY spectrum of 1 . The hydroperoxy-bearing methine unit at $\delta_{\mathrm{C}} 88.4$ was more shielded than that expected for a hydroxy-bearing methine [5,6], and was correlated to the methine proton appearing at $\delta_{\mathrm{H}} 4.38$ in the HMQC spectrum. Thus, the remaining hydroxy group should be positioned at $\mathrm{C}-13$, as indicated by the key ${ }^{1} \mathrm{H}-{ }^{1} \mathrm{H}$ COSY correlations and characteristic NMR signals. 
Figure 2. ${ }^{1} \mathrm{H}-{ }^{1} \mathrm{H}$ COSY and selected HMBC correlations (protons $\rightarrow$ quaternary carbons) for $\mathbf{1}$.

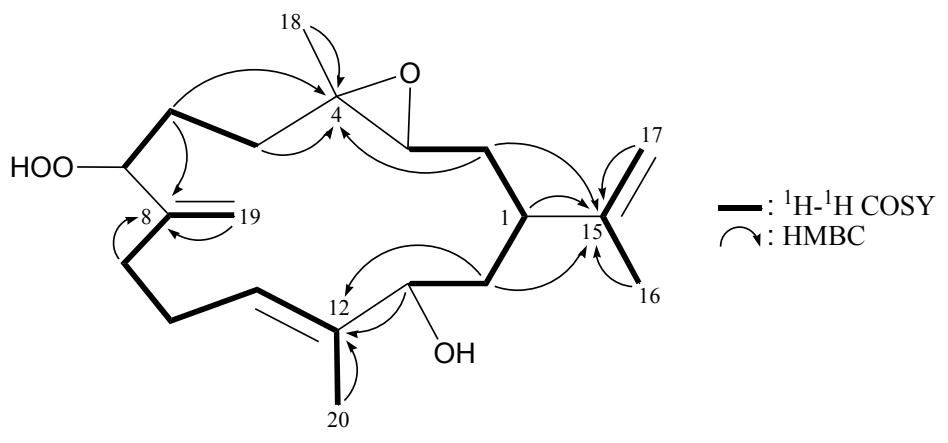

The relative configuration of $\mathbf{1}$ was elucidated mainly from a NOESY spectrum. In the NOESY experiment for 1 (Figure 3), H-1 correlated with $\mathrm{H}-13$, but not with $\mathrm{H}-3$ and $\mathrm{H}_{2}-14$, and $\mathrm{H}-3$ showed correlations with $\mathrm{H}_{2}-14$, revealing the $S^{*}-, R^{*}$ - and $R^{*}$-configurations of the chiral carbons $\mathrm{C}-1, \mathrm{C}-3$ and C-13, respectively, by modeling analysis. $\mathrm{H}-3$ did not exhibit correlation with $\mathrm{H}_{3}-18$, reflecting the trans stereochemistry of 3,4-epoxide. Additionally, correlations between $\mathrm{H}-11$ and $\mathrm{H}-13$, as well as the lack of correlation between $\mathrm{H}-11 / \mathrm{H}_{3}-20$, reflected the $E$ geometry of the double bond at $\mathrm{C}-11 / 12$. Furthermore, by comparison of the proton chemical shift and coupling pattern of $\mathrm{H}-7$ in $\mathbf{1}\left(\delta_{\mathrm{H}} 4.38 \mathrm{dd}\right.$, $J=7.2,4.8 \mathrm{~Hz})$ with those of known cembrane analogues, manaarenolides A $\left(\delta_{\mathrm{H}} 4.52, \mathrm{t}, J=3.5 \mathrm{~Hz}\right)$ and $\mathrm{B}\left(\delta_{\mathrm{H}} 4.40 \mathrm{dd}, J=11.5,3.5 \mathrm{~Hz}\right)$, which were found to possess $7 \alpha$ - and $7 \beta$-hydroperoxy group in their structures, respectively [5], the 7-hydroperoxy group in $\mathbf{1}$ was proven to be $\beta$-oriented and possessing an $S^{*}$-configuration.

Figure 3. Key NOESY correlations of $\mathbf{1}$.

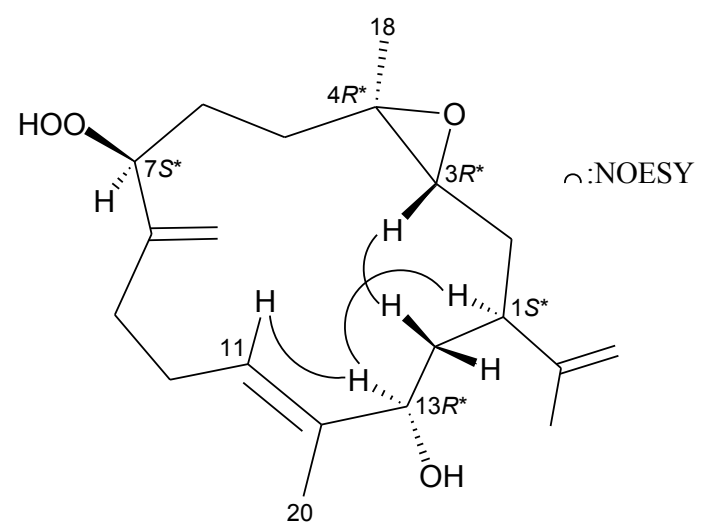

The HRESIMS spectrum of 2 (arbolide B) exhibited a pseudomolecular ion at $\mathrm{m} / \mathrm{z} 327.2298$ $[\mathrm{M}+\mathrm{Na}]^{+}$, consistent with the molecular formula $\mathrm{C}_{20} \mathrm{H}_{32} \mathrm{O}_{2}$ and implying five degrees of unsaturation. The IR spectrum revealed the presence of hydroxy group $\left(v_{\max } 3419 \mathrm{~cm}^{-1}\right)$. The structure of cembrane 2 was deduced from its ${ }^{13} \mathrm{C}$ NMR and DEPT spectra (Table 2), which showed that this compound has 20 carbons, including four methyls, seven methylenes (including an $\mathrm{sp}^{2} \mathrm{CH}_{2}$ ), five methines (including two $\mathrm{sp}^{2} \mathrm{CH}$ ) and four quaternary carbons (including three $\mathrm{sp}^{2}$ quaternary carbons). From the ${ }^{1} \mathrm{H}$ and ${ }^{13} \mathrm{C}$ NMR spectra (Table 2), 2 was found to possess three olefinic groups $\left(\delta_{\mathrm{H}} 5.05,1 \mathrm{H}, \mathrm{ddq}, J=6.4\right.$, $6.4,1.2 \mathrm{~Hz} ; \delta_{\mathrm{C}} 123.2, \mathrm{CH} ; 135.1, \mathrm{C} ; \delta_{\mathrm{H}} 5.34,1 \mathrm{H}, \mathrm{dd}, J=6.4,6.4 \mathrm{~Hz} ; \delta_{\mathrm{C}} 127.2, \mathrm{CH} ; 135.8, \mathrm{C} ; \delta_{\mathrm{H}} 4.71$, $1 \mathrm{H}, \mathrm{dd}, J=2.0,1.6 \mathrm{~Hz} ; 4.64,1 \mathrm{H}, \mathrm{dd}, J=1.6,0.8 \mathrm{~Hz} ; \delta_{\mathrm{C}} 147.6, \mathrm{C} ; 111.0, \mathrm{CH}_{2}$ ). Signals at $\delta_{\mathrm{C}} 63.3$ 
$(\mathrm{CH}), 60.6(\mathrm{C}), 16.7\left(\mathrm{CH}_{3}\right)$ and $\delta_{\mathrm{H}} 2.74(1 \mathrm{H}, \mathrm{dd}, J=10.0,2.8 \mathrm{~Hz}), 1.23(3 \mathrm{H}, \mathrm{s})$ revealed the presence of a methyl-containing trisubstituted epoxide. Detailed analysis of the ${ }^{1} \mathrm{H}-{ }^{1} \mathrm{H}$ COSY and $\mathrm{HMBC}$ correlations (Table 2 and Figure 4) further established the planar structure of 2 as a cembrane-type diterpenoid bearing a hydroxy group at $\mathrm{C}-13$, two trisubstituted carbon-carbon double bonds at C-7/8 and C-11/12, a 1,1-disubstituted carbon-carbon double bond at C-15/17 and a methyl-containing epoxide at $\mathrm{C}-3 / 4$.

Table 2. ${ }^{1} \mathrm{H}\left(400 \mathrm{MHz}, \mathrm{CDCl}_{3}\right)$ and ${ }^{13} \mathrm{C}\left(100 \mathrm{MHz}, \mathrm{CDCl}_{3}\right) \mathrm{NMR}$ data, ${ }^{1} \mathrm{H}-{ }^{1} \mathrm{H}$ COSY and HMBC correlations for cembrane 2.

\begin{tabular}{|c|c|c|c|c|}
\hline Position & $\delta_{\mathrm{H}}(J$ in $\mathrm{Hz})$ & $\delta_{\mathrm{C}}$, Multiple & ${ }^{1} \mathrm{H}-{ }^{1} \mathrm{H}$ COSY & HMBC \\
\hline 1 & $2.01 \mathrm{~m}$ & $40.7, \mathrm{CH}$ & $\mathrm{H}_{2}-2, \mathrm{H}_{2}-14$ & $C-3,-13,-15$ \\
\hline 2 & $1.77 \mathrm{~m} ; 1.31 \mathrm{~m}$ & $33.5, \mathrm{CH}_{2}$ & $\mathrm{H}-1, \mathrm{H}-3$ & $C-1,-3,-4,-14,-15$ \\
\hline 3 & $2.74 \mathrm{dd}(10.0,2.8)$ & $63.3, \mathrm{CH}$ & $\mathrm{H}_{2}-2$ & $\mathrm{C}-2$ \\
\hline 4 & & $60.6, \mathrm{C}$ & & \\
\hline 5 & $2.06 \mathrm{~m} ; 1.27 \mathrm{~m}$ & $38.1, \mathrm{CH}_{2}$ & $\mathrm{H}_{2}-6$ & $C-3,-4,-6,-7$ \\
\hline 6 & $2.29 \mathrm{~m} ; 2.10 \mathrm{~m}$ & $24.0, \mathrm{CH}_{2}$ & $\mathrm{H}_{2}-5, \mathrm{H}-7$ & $C-4,-5,-7,-8$ \\
\hline 7 & $5.05 \mathrm{ddq}(6.4,6.4,1.2)$ & $123.2, \mathrm{CH}$ & $\mathrm{H}_{2}-6, \mathrm{H}_{3}-19$ & $C-6,-9,-19$ \\
\hline 8 & & 135.1, C & & \\
\hline 9 & $2.20 \mathrm{~m} ; 2.04 \mathrm{~m}$ & $38.8, \mathrm{CH}_{2}$ & $\mathrm{H}_{2}-10$ & $C-7,-8,-10,-11,-19$ \\
\hline 10 & $2.16 \mathrm{~m}$ & 24.1, $\mathrm{CH}_{2}$ & $\mathrm{H}_{2}-9, \mathrm{H}-11$ & $C-8,-9,-11,-12$ \\
\hline 11 & $5.34 \mathrm{dd}(6.4,6.4)$ & 127.2, $\mathrm{CH}$ & $\mathrm{H}_{2}-10$ & $C-9,-10,-13,-20$ \\
\hline 12 & & $135.8, \mathrm{C}$ & & \\
\hline 13 & 3.87 br d (10.0) & 75.3, $\mathrm{CH}$ & $\mathrm{H}_{2}-14$ & $\mathrm{C}-11,-20$ \\
\hline \multirow[t]{2}{*}{14} & 1.82 ddd $(13.6,10.8,2.8)$ & $37.3, \mathrm{CH}_{2}$ & H-1, H-13 & $C-1,-2,-12,-15$ \\
\hline & 1.73 ddd $(13.6,10.0,3.6)$ & & & \\
\hline 15 & & 147.6, C & & \\
\hline 16 & $1.67 \mathrm{br} \mathrm{s}$ & $18.5, \mathrm{CH}_{3}$ & $\mathrm{H}_{2}-17$ & $C-1,-15,-17$ \\
\hline 17 & $4.71 \mathrm{dd}(2.0,1.6) ; 4.64 \mathrm{dd}(1.6,0.8)$ & 111.0, $\mathrm{CH}_{2}$ & $\mathrm{H}_{3}-16$ & $C-1,-15,-16$ \\
\hline 18 & $1.23 \mathrm{~s}$ & $16.7, \mathrm{CH}_{3}$ & & $C-3,-4,-5$ \\
\hline 19 & $1.63 \mathrm{br} \mathrm{s}$ & $16.2, \mathrm{CH}_{3}$ & $\mathrm{H}-7$ & $C-7,-8,-9$ \\
\hline 20 & $1.67 \mathrm{~s}$ & $13.0, \mathrm{CH}_{3}$ & & $\mathrm{C}-11,-12,-13$ \\
\hline
\end{tabular}

Figure 4. ${ }^{1} \mathrm{H}-{ }^{1} \mathrm{H}$ COSY and selected HMBC correlations (protons $\rightarrow$ quaternary carbons) for 2.

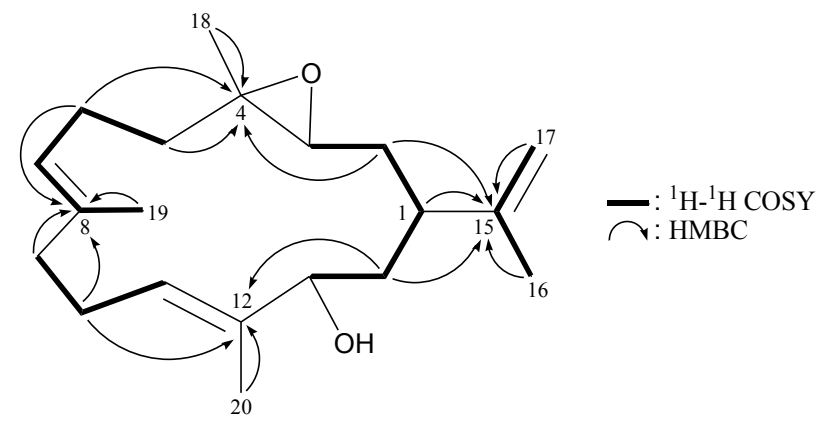

The relative structure of 2 was elucidated by analysis of NOESY correlations, as shown in Figure 5. In the NOESY experiment for 1, H-1 correlated with $\mathrm{H}-13$, but not with $\mathrm{H}-3$, and $\mathrm{H}-3$ showed correlations with $\mathrm{H}_{2}-14$, but not with $\mathrm{H}_{3}-18$ revealing the $S^{*}-, R^{*}, R^{*}$ - and $R^{*}$-configurations of the 
chiral carbons C-1, C-3, C-4 and C-13, respectively, by modeling analysis. Correlations observed between $\mathrm{H}-7 / \mathrm{H}_{2}-9$ and $\mathrm{H}-11 / \mathrm{H}-13$, as well as the lack of correlation between $\mathrm{H}-7 / \mathrm{H}_{3}-19$ and $\mathrm{H}-11$ / $\mathrm{H}_{3}-20$, reflected the $E$ geometry of the double bonds at C-7/8 and C-11/12.

Figure 5. The NOESY correlations of 2.

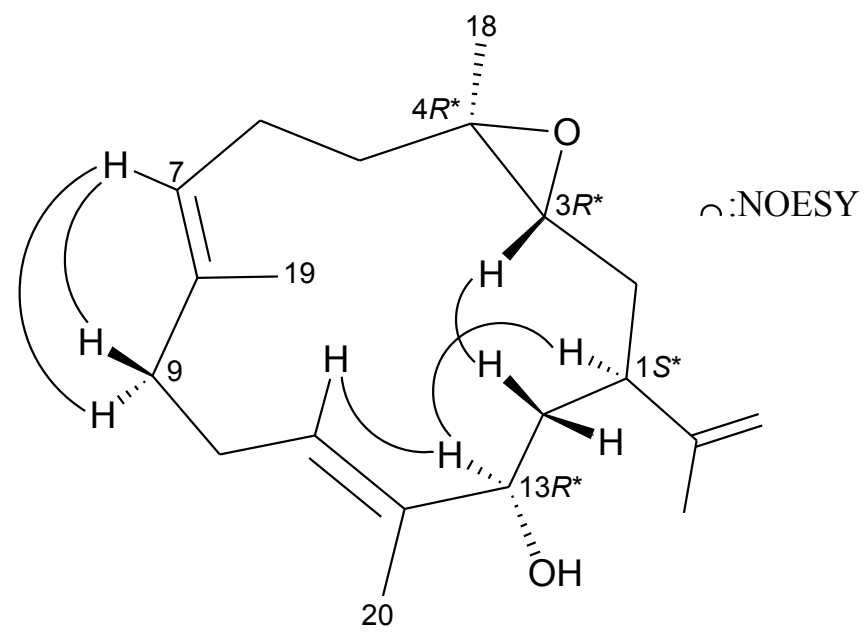

The steroid 3 was found to be identical with the known compound, crassarosterol A, which was first isolated from a Formosan soft coral Sinularia crassa, on the basis of the comparison of its physical and spectroscopic data with those reported previously [4].

Cytotoxicity of compounds 1-3 toward K562 (human erythromyeloblastoid leukemia), MOLT-4 (human acute lymphoblastic leukemia), HTC-116 (human acute promyelocytic leukemia), DLD-1 (human colorectal adenocarcinoma), T-47D (human breast ductal carcinoma), MDA-MB-231 (human breast adenocarcinoma) and MCF-7 (human breast adenocarcinoma) cells was studied, and the results are shown in Table 3. These data showed that crassarosterol A (3) exhibited significant cytotoxicity towards K562 and MOLT-4 leukemia.

Table 3. Cytotoxic data of compounds 1-3.

\begin{tabular}{cccccccc}
\hline & \multicolumn{7}{c}{ Cell lines IC $_{\mathbf{5 0}}(\boldsymbol{\mu} \mathbf{g} / \mathbf{m L})$} \\
\cline { 2 - 8 } Compounds & K562 & MOLT-4 & HTC-116 & DLD-1 & T-47D & MDA-MB-231 & MCF-7 \\
\hline $\mathbf{1}$ & NA & NA & NA & NA & NA & NA & NA \\
$\mathbf{2}$ & NA & 19.0 & NA & NA & NA & NA & NA \\
$\mathbf{3}$ & 2.5 & 0.7 & 19.0 & NA & NA & NA & NA \\
Doxorubicin $^{a}$ & 0.3 & 0.001 & 0.06 & 1.1 & 0.3 & 0.4 & 10.0 \\
\hline
\end{tabular}

${ }^{a}$ Doxorubicin was used as a positive control. NA $=$ not active at $20 \mu \mathrm{g} / \mathrm{mL}$ for $72 \mathrm{~h}$.

\section{Experimental Section}

\subsection{General Experimental Procedures}

Optical rotations were measured at a Jasco P-1010 digital polarimeter (Japan Spectroscopic Corporation, Tokyo, Japan). Infrared spectra were recorded on a Varian Diglab FTS 1000 FT-IR spectrometer (Varian Inc. Palo Alto, CA, USA); peaks are reported in $\mathrm{cm}^{-1}$. NMR spectra were 
recorded on a Varian Mercury Plus 400 NMR spectrometer (Varian Inc.) using the residual $\mathrm{CHCl}_{3}$ signal $\left(\delta_{\mathrm{H}} 7.26 \mathrm{ppm}\right)$ as the internal standard for ${ }^{1} \mathrm{H} \mathrm{NMR}$ and $\mathrm{CDCl}_{3}\left(\delta_{\mathrm{C}} 77.1 \mathrm{ppm}\right)$ for ${ }^{13} \mathrm{C} \mathrm{NMR}$. Coupling constants $(J)$ are given in Hz. ESIMS and HRESIMS were recorded using a Bruker APEX II mass spectrometer (Bruker, Bremen, Germany). Column chromatography was performed on silica gel (230-400 mesh, Merck, Darmstadt, Germany). TLC was carried out on precoated Kieselgel $60 \mathrm{~F}_{254}$ ( $0.25 \mathrm{~mm}$, Merck); spots were visualized by spraying with $10 \% \mathrm{H}_{2} \mathrm{SO}_{4}$ solution followed by heating. The normal phase HPLC (NP-HPLC) was performed using a system comprised of a Hitachi L-7110 pump (Hitachi Ltd. Tokyo, Japan) and a Rheodyne 7725 injection port (Rheodyne LLC, Rohnert Park, CA, USA). Two normal phase columns (Supelco Ascentis ${ }^{\circledR}$ Si Cat \#:581515-U, $25 \mathrm{~cm} \times 21.2 \mathrm{~mm}$, $5 \mu \mathrm{m}$; 581514-U, $25 \mathrm{~cm} \times 10 \mathrm{~mm}, 5 \mu \mathrm{m}$, Sigma-Aldrich. Com. St. Louis, MO, USA) were used for NP-HPLC.

\subsection{Animal Material}

Specimens of the octocoral Sinularia arborea [8] were collected by hand using scuba equipment off the coast of southern Taiwan in October, 2012, and stored in a freezer $\left(-20{ }^{\circ} \mathrm{C}\right)$ until extraction. A voucher specimen (NMMBA-TWSC-1200X) was deposited in the National Museum of Marine Biology and Aquarium, Taiwan.

\subsection{Extraction and Isolation}

Specimens of the soft coral Sinularia arborea (wet weight $1.6 \mathrm{~kg}$, dry weight $576 \mathrm{~g}$ ) were minced and extracted with ethyl acetate (EtOAc). The EtOAc extract left after removal of the solvent (12.5 g) was separated by silica gel and eluted using a mixture of $n$-hexane/EtOAc in a stepwise fashion from 100:1-pure EtOAc to yield 11 fractions A-K. Fraction G was separated by NP-HPLC, using a mixture of $n$-hexane and acetone (6:1) to yield 26 subfractions G1-G26. Fraction G13 was repurified by NP-HPLC, using a mixture of $n$-hexane and EtOAc (4:1) to yield 9 subfractions G13A-G13I. Fraction G13G was repurified by NP-HPLC, using a mixture of $n$-hexane and acetone (7:2, flow rate: $2.0 \mathrm{~mL} / \mathrm{min})$ to yield $2\left(3.7 \mathrm{mg}, t_{\mathrm{R}}=8 \mathrm{~m}\right)$. Fraction G13I was repurified by NP-HPLC, using a mixture of dichloromethane and acetone $(10: 1$, flow rate: $1.0 \mathrm{~mL} / \mathrm{min})$ to yield $1\left(2.9 \mathrm{mg}, t_{\mathrm{R}}=332 \mathrm{~m}\right)$. Fraction $\mathrm{H}$ was purified by NP-HPLC, using a mixture of $n$-hexane and EtOAc $(2: 1)$ to obtain 14 subfractions H1-H14. Fraction H12 was repurified by NPLC, using a mixture of $n$-hexane and acetone $(3: 1$, flow rate: $2.0 \mathrm{~mL} / \mathrm{min})$ to yield $3\left(1.2 \mathrm{mg}, t_{\mathrm{R}}=149 \mathrm{~m}\right)$.

Arbolide A (1): colorless oil; $[\alpha]_{\mathrm{D}}^{25}+12\left(c 0.15, \mathrm{CHCl}_{3}\right)$; IR (neat) $v_{\max } 3445 \mathrm{~cm}^{-1} ;{ }^{1} \mathrm{H}(400 \mathrm{MHz}$, $\left.\mathrm{CDCl}_{3}\right)$ and ${ }^{13} \mathrm{C}\left(100 \mathrm{MHz}, \mathrm{CDCl}_{3}\right) \mathrm{NMR}$ data, see Table 1; ESIMS: $m / z 359[\mathrm{M}+\mathrm{Na}]^{+}$; HRESIMS: $m / z 359.2195$ (calcd for $\mathrm{C}_{20} \mathrm{H}_{32} \mathrm{O}_{4} \mathrm{Na}, 359.2198$ ).

Arbolide B (2): colorless oil; $[\alpha]_{\mathrm{D}}^{25}-3\left(c \quad 0.19, \mathrm{CHCl}_{3}\right)$; IR (neat) $v_{\max } 3419 \mathrm{~cm}^{-1} ;{ }^{1} \mathrm{H}(400 \mathrm{MHz}$, $\left.\mathrm{CDCl}_{3}\right)$ and ${ }^{13} \mathrm{C}\left(100 \mathrm{MHz}, \mathrm{CDCl}_{3}\right) \mathrm{NMR}$ data, see Table 2; ESIMS: $m / z 327[\mathrm{M}+\mathrm{Na}]^{+}$; HRESIMS: $m / z 327.2298$ (calcd for $\mathrm{C}_{20} \mathrm{H}_{32} \mathrm{O}_{2} \mathrm{Na}, 327.2300$ ).

Crassarosterol A (3): white powder; $[\alpha]_{\mathrm{D}}^{25}-16\left(c 0.06, \mathrm{CHCl}_{3}\right)$ (ref. [4], [ $\left.\alpha\right]_{\mathrm{D}}^{24}-45\left(c 0.66, \mathrm{CHCl}_{3}\right)$ ); IR (neat) $v_{\max } 3396 \mathrm{~cm}^{-1}$; ESIMS: $m / z 453[\mathrm{M}+\mathrm{Na}]^{+}$. The ${ }^{1} \mathrm{H}$ and ${ }^{13} \mathrm{C}$ NMR data of 3 are in full agreement with those reported previously [4]. 


\subsection{Cytotoxicity Testing}

Cytotoxicity of compounds 1-3 was assayed with a modification of the MTT [3-(4,5-dimethylthiazol-2-yl)-2,5-diphenyltetrazolium bromide] colorimetric method. Cytotoxicity assays were carried out according to previously described procedures $[9,10]$.

\section{Conclusions}

In our continuing investigation on the chemical constituents of marine invertebrates collected off the waters of Taiwan, the soft coral Sinularia arborea has resulted in the isolation of two new cembrane-type diterpenoids, arbolides A (1) and B (2) and a known trihydroxysteroid crassarosterol A (3) [4]. Steroid 3 was found to exhibit selective cytotoxicity toward the human leukemia K562 and MOLT-4 cells. To the best of our knowledge, this is the first time that the natural substances from Sinularia arborea have been reported.

\section{Acknowledgments}

This research was supported by grants from the National Dong Hwa University; the National Museum of Marine Biology and Aquarium; the Division of Marine Biotechnology, Asia-Pacific Ocean Research Center, National Sun Yat-sen University; and the National Science Council (Grant No. NSC 102-2325-B-291-001 and 101-2320-B-291-001-MY3), Taiwan, awarded to P.-J.S.

\section{Conflicts of Interest}

The authors declare no conflict of interest.

\section{References}

1. Chen, W.-T.; Li, Y.; Guo, Y.-W. Terpenoids of Sinularia soft corals: Chemistry and bioactivity. Acta Pharm. Sin. B 2012, 2, 227-237.

2. Yang, B.; Zhou, X.-F.; Lin, X.-P.; Liu, J.; Peng, Y.; Yang, X.-W.; Liu, Y. Cembrane diterpenes chemistry and biological properties. Curr. Org. Chem. 2012, 16, 1512-1539.

3. Rocha, J.; Peixe, L.; Gomes, N.C.M.; Calado, R. Cnidarians as a source of new marine bioactive compounds - an overview of the last decade and future steps for bioprospecting. Mar. Drugs 2011, 9, 1860-1886.

4. Chao, C.-H.; Chou, K.-J.; Huang, C.-Y.; Wen, Z.-H.; Hsu, C.-H.; Wu, Y.-C.; Dai, C.-F.; Sheu, J.-H. Steroids from the soft coral Sinularia crassa. Mar. Drugs 2012, 10, 439-450.

5. Su, J.-H.; Ahmed, A.F.; Sung, P.-J.; Chao, C.-H.; Kuo, Y.-H.; Sheu, J.-H. Manaarenolides A-I, diterpenoids from the soft coral Sinularia manaarensis. J. Nat. Prod. 2006, 69, 1134-1139.

6. Fattorusso, E.; Romano, A.; Taglialatela-Scafati, O.; Irace, C.; Maffettone, C.; Bavestrello, G.; Cerrano, C. Oxygenated cembranoids of the decaryiol type from the Indonesian soft coral Lobophytum sp. Tetrahedron 2009, 65, 2898-2904. 
7. Lin, W.-Y.; Lu, Y.; Su, J.-H.; Wen, Z.-H.; Dai, C.-F.; Kuo, Y.-H.; Sheu, J.-H. Bioactive cembranoids from the Dongsha atoll soft coral Sarcophyton crassocaule. Mar. Drugs 2011, 9, 994-1006.

8. Verseveldt, J. Octocorallia from North-Western Madagascar (Part II). Zool. Verh. 1971, 117, 1-73.

9. Alley, M.C.; Scudiero, D.A.; Monks, A.; Hursey, M.L.; Czerwinski, M.J.; Fine, D.L.; Abbott, B.J.; Mayo, J.G.; Shoemaker, R.H.; Boyd, M.R. Feasibility of drug screening with panels of human tumor cell lines using a microculture tetrazolium assay. Cancer Res. 1988, 48, 589-601.

10. Scudiero, D.A.; Shoemaker, R.H.; Paull, K.D.; Monks, A.; Tierney, S.; Nofziger, T.H.; Currens, M.J.; Seniff, D.; Boyd, M.R. Evaluation of a soluble tetrazolium/formazan assay for cell growth and drug sensitivity in culture using human and other tumor cell lines. Cancer Res. 1988, $48,4827-4833$.

(C) 2013 by the authors; licensee MDPI, Basel, Switzerland. This article is an open access article distributed under the terms and conditions of the Creative Commons Attribution license (http://creativecommons.org/licenses/by/3.0/). 